\title{
ANALISIS PENERAPAN SAK EMKM PADA PENYUSUNAN LAPORAN KEUANGAN UMKM DI KOTA BATAM
}

\author{
Mortigor Afrizal Purba \\ Dosen Program Studi Akuntansi, Universitas Putera Batam \\ email: mortigor@ puterabatam.ac.id
}

\begin{abstract}
Seeing the importance of applying accounting for UMKM, the IAI as a professional organization as well as a compiler of Financial Accounting Standards (SAK) through the Financial Accounting Standards Board (DSAK) composes accounting standards that are consistent with the characteristics of UMKM. Based on the results of the study, it can be concluded that, (1) Bookkeeping carried out on UMKM is still limited to business reports which are prepared not in accordance with financial accounting standards, but the entity considers them as financial statements. (2) The entity has not conducted accounting procedures in accounting. (3) UMKM have not implemented SAK-EMKM. (4) The entity has not been able to present financial statements in accordance with the SAK-EMKM.
\end{abstract}

Keywords: SAK EMKM; UMKM

\section{PENDAHULUAN}

Bidang usaha mikro, kecil, dan menengah yang biasa disingkat UMKM adalah kegiatan ekonomi kerakyatan mandiri dan berskala kecil yang pengelolaannya dilakukan oleh kelompok masyarakat, keluarga, atau perorangan. Kenyataannya UMKM memberikan pengaruh yang besar terhadap perekonomian skala nasional, karena dapat menyerap jumlah pengangguran dan menyumbang kontribusi lumayan tinggi terhadap Produk Domestik Bruto (PDB). Data menunjukkan bahwa tahun 2013 jumlah UMKM yang ada di Indonesia lebih dari 50\%. UMKM juga mampu menyerap tenaga kerja produktif sebanyak $97 \%$ dari keseluruhan total tenaga kerja yang ada untuk usaha UMKM yang saat ini tersedia di Indonesia. Bersama dengan Koperasi, UMKM mampu juga memberikan sumbangan positif sebesar 5\% terhadap PDB di Indonesia. Maka dari itu tidaklah salah jika ada yang menyatakan bahwa UMKM berperan sebagai tulangpunggung perekonomian nasional. Untuk mengembangkan usaha menjadi lebih besar UMKM selalu terkendala dengan masalah bagaimana memperoleh modal kerja.

Melihat pentingnya penerapan akuntansi bagi UMKM dan dengan memperhatikan karekteristik transaksi UMKM, maka Dewan Standar Akuntansi Keuangan (DSAK) dibawah naungan Ikatan Akuntan Indonesia (IAI) berupaya menerbitkan satu standar akuntansi yang sesuai. Pada tahun 2009, DSAK telah mengesahkan SAK-EMKM (Standar Akuntansi Keuagan Ekonomi Mikro Kecil Menengah) dan sejak tanggal 1 Januari 2018 standar ini dinyatakan berlaku efektif. SAK-EMKM adalah standar akuntansi untuk entitas yang tidak memiliki akuntabilitas kepada publik. Dengan adanya standar ini maka perusahaan kecil dan menengah mampu menyusun laporan keuangannya untuk mendapatkan dana dan pengembangan usaha (Hetika \& Nurul Mahmudah, 2017)

Di kota Batam terdapat 2.627 jenis UMKM yang terdaftar di Dinas Koperasi dan Usaha Mikro data terakhir pada Tahun 2018, yang mana jenis usahanya terdiri dari jasa, perdagangan, makanan/minuman, kerajinan, pertanian, dan produksi. Masih banyak UMKM yang terdapat di Kota Batam yang beum melakukan pencatatan pembukuan sesuai stnadar akuntansi. Ini bisa disebabkan oleh kurangnya pengetahuan, pengertian, keperdulian, dan pengetahuan terhadap ilmu dasar akuntansi, dan tingkat pendidikan pelaku usaha yang belum memadai, serta adanya persepsi dalam pelaku UMKM bahwa pembukuan tidak penting dalam usahanya. Manajemen 
UMKM belum melakukan pembukuan dalam pelaporan keuangannya sesuai dengan Standar Akuntansi yang berlaku, tetapi pelaku UMKM hanya melakukan pembukuan berupa kas masuk dan kas keluar dalam transaksi usaha mereka. Pengadaan program latihan tentang akuntansi, pemahaman, dan sosialisasi SAK-EMKM, maka kedepannya manajemen UMKM di kota Batam dapat membuat laporan keuangan dengan benar, yang mana hal ini akan memudahkan UMKM dalam melakukan pinjaman dana kepada lembaga keuangan (bank) untuk mengembangkan usaha mereka.

UMKM harus mampu menerbitkan laporan keuangan agar dapat lebih mudah untuk memiliki akses ke lembaga pemberi kredit. Sangat disayangkan bahwa kenyataan di lapangan memperlihatkan bahwa masih banyak UMKM tidak mampu membuat melakukan pelaporan keuangan yang dibutuhkan oleh pemberi kredit sehingga membuat pihak perbankan bank harus menerapkan prinsip kehati-hatian lebih serius dalam memberikan pinjaman (Rias, 2009).

Setelah menganalisis keseluruhan penjelasan di atas maka peneliti menetapkan judul untuk penelitian ini sebagai berikut: ANALISIS PENERAPAN SAK-EMKM PADA PENYUSUNAN LAPORAN KEUANGAN UMKM DI KOTA BATAM.

\section{Perumusan Masalah}

UMKM memberikan sumbangan yang sangat signifikan dalam perekonomian nasional. Hal lain menunjukkan bahwa dengan adanya UMKM juga dapat memberikan kontribusi positif bagi masyarakat Indonesia sehingga dapat tetap bertahan dari krisis keuangan yang melanda berbagai belahan dunia yang berdampak pada ekonomi nasional dan daerah. Oleh karena itu UMKM harus didorong untuk mampu menghasilkan keuntungan yang lebih besar, dengan cara melakukan pelaporan keuangan yang patuh kepada standar dan prinsip akuntansi yang berlak umum.

SAK-EMKM adalah standar akuntansi yang mengatur tentang bagaimana pelaporan keuangan yang baku bagi UMKM. Pengusaha UMKM dianjurkan untuk memanfaatkan standar akuntansi untuk bisa memaksimalkan keuntungan. Akan tetapi pemerintah harus mengambil peran yang lebih banyak lagi dalam sosialisasi SAK-EMKM kepada pelaku usaha UMKM. Kenyataan di lapangan menunjukkan bahwa sejauh ini pemerintah Kota Batam terlihat sangat kurang melakukan sosialisasi standar akuntansi tersebut, sehingga penerapan SAK-EMKM kepada UMKM di Kota Batam menjadi salah satu isu yang menarik untuk diteliti. Dibawah ini disajikan pertanyaan penelitian yang akan dijadikan sebagai rumusan masalah dalam penelitian ini, yaitu:

1. Bagaimana proses pembukuan akuntansi pada UMKM di Kelurahan Tanjung Riau Kecamatan Sekupang Kota Batam.

2. Apakah pembukuan akuntansi pada UMKM di Kelurahan Tanjung Riau Kecamatan Sekupang Kota Batam sudah menerapkan SAK-EMKM

3. Apa kendala yang dialami pelaku usaha UMKM dalam melakukan pembukuan akuntansi yang sesuai SAK-EMKM di Kelurahan Tanjung Riau Kecamatan Sekupang Kota Batam.

\section{TINJAUAN PUSTAKA}

\section{Standar Akuntansi Entitas Tanpa Akuntabilitas Publik}

Laporan keuangan yang diterbitkan oleh pelaku usaha di Indonesia harus patuh kepada standar akuntansi keuangan yang disusun oleh Dewan Standar Akuntansi Keuangan (DSAK) dibawah naungan Ikatan Akuntan Indonesia (IAI). IAI adalah satu-satunya organisasi profesi di Indonesia yang beranggotakan para akuntan yang diberikan kewenangan oleh negara untuk menyusun dan menerbitkan standar dimaksud.

SAK harus dijadikan sebagai rujukan dalam penyusunan serta penyajian laporan keuangan. IAI menyusun dan menyiapkan Standar Akuntansi Keuangan bagi Entitas tanpa Akuntabilitas Publik (SAK-EMKM). Dengan demikian UMKM tidak perlu menerbitkan laporan keuangan yang sesuai dengan SAK dengan dikeluarkannya SAK-EMKM ini.

Standard akuntansi keuangan untuk bidang usaha yang dikategorikan sebagai entitas tanpa akuntabilatas public adalah SAK-EMKM. Disiapkan oleh delapan belas anggota Dewan 
Standard Akuntansi Keuangan pada bulan Mei tahun 2009 di Jakarta. Terdiri dari tiga puluh bab yang dilampiri dengan glossary atau daftar istilah di bagian akhir yang memudahkan para pembaca untuk memahami isinya dengan mudah.

Menurut (Ikatan Akuntan Indonesia, 2009: 1.1) di dalam SAK-EMKM, bahwa yang dimaksud dengan Ekonomi Mikro Kecil Menengah adalah:

1. Unit usaha atau entitas yang tida memerlukan akuntabilitas publik secara signifikan

2. Entitas yang menerbitkan laporan keuangan untuk tujuan yang umum (general purpose financial statement) bagi pengguna di luar perusahaan. Pengguna eksternal adalah stakeholder yang tidak terlibat langsung dalam mengelola kegiatan usaha, pemberi kredit, dan lembaga lainnya, misalnya: pemeringkat kredit.

Entitas yang memiliki akuntabilitas publik yang signifikan jika:

1. Telah menyerahkan pernyataan pendaftaran, atau dalam proses mengajukan pernyataan pendaftaran, kepada otoritas pasar modal atau regulator lainnya untuk tujuan penerbitan sekuritas di pasar modal; atau

2. Menguasai aset dan kapasitas fidusia untuk sekelompok besar orang, seperti bank, perusahaan asuransi, broker dan / atau pedagang sekuritas, dana pensiun, reksadana dan bank investasi.

SAK-EMKM adalah Standar Akuntansi Keuangan Ekonomi Mikro Kecil Menengah. Yaitu untuk entitas yang laporan keuangannya tidak dipublikasikan sehingga diketahui secara luas oleh publik, dimana SAK-EMKM diterapkan oleh usaha mikro kecil dan menengah.

\section{Tujuan Laporan Keuangan}

Menurut (Ikatan Akuntan Indonesia, 2017) dalam PSAK No.1 disebutkan bahwa laporan keuangan bertujuan agar dapat dibandingkan dengan laporan keuangan periode sebelumnya maupun laporan keuangan untuk usaha sejenis lainnya.

Menurut (Kasmir, 2014:112) dalam bukunya Analisis Laporan Keuangan, ada tujuh mengapa unit usaha harus menerbitkan laporan keuangan, yakni:

a) Menampilkan informasi tentang jenis dan jumlah utang dan modal yang dimiliki perusahaan saat ini

b) Menampilkan informasi tentang harta perusahaan saat ini

c) Menampilkan informasi tentang perubahan yang terjadi terhadap aktiva, pasiva, dan modal perusahaan

d) Menampilkan informasi tentang jenis dan jumlah pendapatan yang diperoleh perusahaan pada suatu periode tertentu

e) Menampilkan informasi tentang catatan atas laporan keuangan

f) Menampilkan informasi tentang kinerja sumber daya manajemen perusahaan dalam suatu periode tertentu

g) Menampilkan informasi keuangan lainnya yang dianggap perlu

Penjelasan diatas memperlihatkan bahwa shareholder, pemberi kredit, investor, dan pemerintah membutuhkan informasi dari perusahaan berupa kinerja dan gambaran umum perusahaan yang disajikan dalam laporan keuangan yang disajikan secara lengkap oleh manajemen perusahaan. Informasi tersebut akan digunakan oleh seluruh pengguna laporan keuangan dalam menentukan keputusan ekonomi pada masa depan.

\section{Usaha Mikro Kecil Menengah (UMKM)}

Dalam Undang-undang Nomor 20 Tahun 2008 (Indonesia, 2008) usaha mikro kecil menengah didefenisikan sebagai berikut:

1. Usaha mikro adalah bisnis yang dimiliki orang perorangan dan/atau badan usaha yang memenuhi syarat usaha mikro produktif.

2. Usaha menengah adalah usaha yang berdiri sendiri, dimiliki oleh orang perorangan, maupun badan usaha yang bukan merupakan anak perusahaan atau cabang perusahaan yang dimiliki/dikuasai yang menjadi bagian baik secara langsung dan tidak langsung dalam skala besar maupun kecil.

3. Usaha kecil adalah usaha yang berdiri sendiri, dimiliki orang perorangan. Merupakan badan usaha yang bukan merupakan perusahaan cabang yang dimiliki dan dikuasai secara 
langsung maupun tidak langsung dari usaha menengah dan besar dan memenuhi syarat usaha kecil, yang sedang dalam keadaan produktif.

Usaha masyarakat dalam skala kecil dengan bidang usaha yang secara umum juga merupakan kegiatan usaha skala kecil serta perlu diberikan perlindungan agar terhindar dari persaingan usaha tidak sehat, juga dikategorikan sebagai UMKM. Hal ini termaktub dalam Keputusan Presiden Republik Indonesia Nomor 99 Tahun 1998.

Sedangkan untuk menghindari dan mencegah persaingan usaha tidak sehat, negara sudah hadir dengan UU No. 5 Tahun 1999 yakni tentang Komisi Pengawas Persaingn Usaha yang disingkat KPPU. Komisi ini hadir untuk mencegah adanya monopoli dalam bisnis. Terjadinya monopoli dalam bisnis akan sangat merugikan pengusaha kecil dan UMKM, karena mereka ini tidak akan mampu bersaing dengan harga yang ditetapkan oleh pelaku monopoli.

\section{Kerangka Berpikir}

Kerangka berpikir disajikan dalam gambar di bawah ini yang dibuat berdasarkan tujuan penelitian dan rumusan masalah yang disajikan sebelumnya.

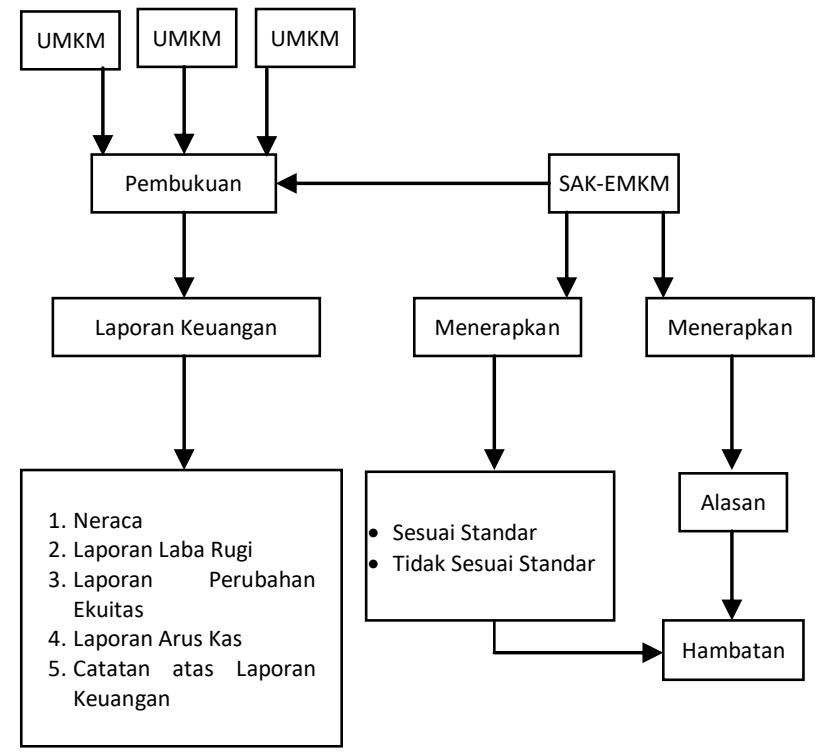

\section{Gambar 1. Kerangka Berpikir}

Penjelasan mengenai kerangka berpikir penelitian tersebut adalah terlebih dahulu dipilih UMKM apa yang akan dijadikan sebagai objek penelitian. Setelah ditentukan akan meneliti tentang UMKM di Kelurahan Tanjung Riau Kecamatan Sekupang Kota Batam selanjutnya penulis mencari tahu tentang pengalaman dan pengetahuan akuntansi yang diketahui oleh UMKM di Kelurahan Tanjung Riau Kecamatan Sekupang, dan apakah UMKM tersebut sudah menerapkan akuntansi dan pembukuan. Apabila UMKM di Kelurahan Tanjung Riau Kecamatan Sekupang sudah membuat laporan keuangan, maka akan dievaluasi apakah sudah sesuai dengan SAK-EMKM atau belum sesuai. Setelah dievaluasi mengenai penerapan SAK-EMKM, tahapan berikutnya adalah analisis atas kendala apa saja yang mempengaruhi penerapan SAK-EMKM pada UMKM di Kelurahan Tanjung Riau Kecamatan Sekupang Kota Batam.

\section{METODE}

\section{Desain Penelitian}

Jenis penelitian deskriptif kualitatif adalah desain penelitian yang digunakan dalam penelitian ini, yakni berupa studi kasus. Penelitian deskriptif adalah penelitian yang menggambarkan mengenai bagaimana keadaan perusahaan tersebut sampai pada data yang 
dibutuhkan untuk membuat laporan keuangan sesuai dengan SAK-EMKM. Penelitian deskriptif pada umumya merupakan penelitian non hipotesis.

Menurut (Sugiono, 2014:30), komponen dan proses penelitian yaitu setiap penelitian akan selalu berangkat dari masalah yang disajikan dalam rumusan masalah. Menyelidiki objek yang tidak dapat diukur dengan angka-angka ataupun ukuran lain yang bersifat matematis.

Gambar di bawah ini akan menyajikan desain penelitian ini:

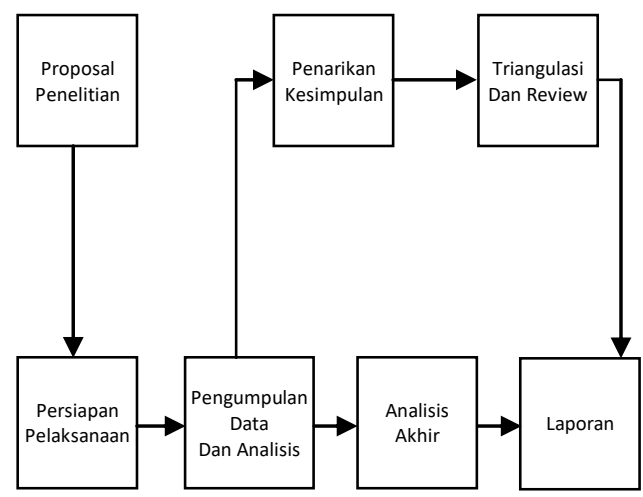

Gambar 2. Desain Penelitian

\section{Populasi dan Pengambilan Sampel}

Menurut (Sugiono, 2014:76), teknik sampling adalah cara untuk menentukan banyaknya sampel yang jumlahnya sesuai dengan ukuran sampel yang akan dijadikan sumber data sesungguhnya, dengan memperhatikan sifat-sifat dan penyebaran populasi agar dapat diambil sampel yang representatif atau benar-benar mewakili populasi.

Teknik penentuan sampel merupakan suatu bentuk spesifik atau proses bagi pemusatan atau pemilihan pada penelitian yang menunjuk pada seleksi. Cuplikan dalam penelitian kualitatif tak jarang juga dinyatakan menjadi internal sampling. Pada cuplikan yang bersifat internal, cuplikan diambil untuk mewakili informasinya menggunakan kelengkapan dan kedalamannya yang tidak perlu ditentukan oleh jumlah asal datanya. Jumlah informan yang kecil bisa saja menjelaskan informasi tertentu secara lebih lengkap dan benar daripada informasi yang diperoleh dari jumlah nara asal yang lebih banyak yang mungkin kurang mengetahui serta tahu informasi yang sebenarnya. Sampling pada penelitian kualitatif dari sifatnya yang internal tersebut menunjuk pada kemungkinan generalisasi teoritis.

Menurut (Arikunto, 2014:14), penelitian kualitatif biasanya menggunakan empat jenis teknik sampling yang biasa digunakan dalam berbagai penelitian, yaitu:

1. Snow ball sampling

2. Cluster / quota sampling

3. Purposive sampling

4. Accidental sampling

Penelitian ini menggunakan teknik sampling nomor dua, yakni cluster / quota sampling. (Arikunto, 2014:15) menyebutkan dalam bukunya bahwa cluster / quota sampling adalah teknik sampling yang digunakan dengan cara memilih sejumlah responden dari sejumlah wilayah tertentu sampai batas data yang diinginkan terpenuhi. Pada teknik ini jumlah populasi tidak diperhitungkan, melainkan adanya proses klasifikasi dalam beberapa kelompok. Sampel diambil dengan menentukan jatah atau quota tertentu pada setiap kelompok yang seakan-akan berkedudukan masing-masing sebagai sub populasi. Pengumpulan data dengan kangsung pada unit sampel yang diteliti. Dalam penelitian ini unit sampling yang diteliti adalah sejumlah UMKM yang berada di Kelurahan Tanjung Riau Kecamatan Sekupang Kota Batam. Berbagai jenis UMKM dikembangkan dengan baik di Kelurahan Tanjung Riau Kecamatan Sekupang Kota Batam sehingga dengan teknik sampling cluster atau quota sampling ini diharapkan dapat menentukan sampel yang paling sesuai dan mampu menjadi wakil dari keseluruhan objek penelitian. 


\section{Teknik Pengumpulan Data}

Cara mengumpulkan data dalam penelitian kualitatif deskriptif secara umum bisa dikelompokan dalam dua cara, yakni: metode atau teknik pengumpulan data yang bersifat interaktif dan yang bersifat non interaktif.

Metode interaktif terdiri dari wawancara dan focus group discussion. Sedangkan yang non interaktif terdiri dari kuesioner, mencatat dokumen atau file arsip. Kecermatan dalam memilih dan menyusun teknik dan alat pengumpul data ini sangat berpengaruh pada objektivitas hasil penelitian.

Penjelasan tersebut menunjukkan bahwa teknik dan alat pengumpulan data yang tepat dalam suatu penelitian akan memungkinkan dicapainya pemecahan masalah secara valid dan reliabel, yang pada gilirannya akan memungkinkan generalisasi yang objektif. berikut :

Pada penelitian ini, teknik pengumpulan data yang penulis gunakan adalah sebagai

a. Wawancara

b. Dokumentasi

\section{HASIL DAN PEMBAHASAN}

\section{Proses Pembukuan Akuntansi pada UMKM di Kelurahan Tanjung Riau}

Pembukuan akuntansi yang dilakukan pada UMKM di Kelurahan Tanjung Riau sangat beraneka ragam, namun pada dasarnya mereka melakukan pembukuannya sebatas pemahaman mereka masing-masing dalam menjalankan usaha. Hal seperti ini yang diungkapkan oleh Informan I sebagai berikut:

"Pembukuan saya lakukan untuk mengontrol keuangan, mulai dari pengeluaran hingga pemasukan setiap harinya tapi hanya sebatas pemahaman dan pengetahuan saya saja. Terus terang saya tidak mampu memahami akuntansi secara detail jadi pembukuan yang saya lakukan sejauh saya bisa mengerti saja. Lagipula untuk melakukan pembukuan yang benar menurut ilmu akuntansi malah terlalu ribet dan menyita banyak waktu."

Wawancaranya dengan penulis, sebagai berikut:

"Pembukuan ya hanya sebatas catatan-catatan keuangan tadi, berupa catatan-catatan penerimaan dan pengeluaran uang saja.jadi tidak ada laporan khusus dalam bentuk laporan keuangan yang lengkap dan rapi."

Berdasarkan hasil wawancara tersebut dapat diketahui bahwa setiap pengeola atau pemilik UMKM memiliki kreatifitas sendiri-sendiri dalam menyusun catatan-catatan usahanya, namun dalam menyusun catatan pembukuan mereka tidak memakai ilmu akuntansi sebagai dasar pembukuan, mereka melakukan pembukuan secara sederhana.

Meskipun dalam pembukuan yang dilakukan relative sederhana, namun pengelola atau pemilik UMKM telah menggunakan bukti-bukti transaksi yang dapat dipertanggungjawabakan. Informasi ini diperoleh dari bukti-bukti dokumen dan pengakuan hasil wawancara yang dilakukan penulis dengan narasumber.

\section{Pembukuan Akuntansi pada UMKM di Kelurahan Tanjung Riau Dilihat dari Standar dalam SAK-EMKM}

Proses pembukuan akuntansi yang terjadi pada UMKM di Kelurahan Tanjung Riau secara garis besar belum menunjukan adanya penerapan SAK-EMKM di dalamnya, bahkan dapat dikatakan para pengelola UMKM di Kelurahan Tanjung Riau belum melakukan pembukuan yang sesuai dengan kaidah dasar yang diyakini dalam ilmu akuntansi. Hal ini diperkuat dengan berbagai bukti yang ditemukan di lapangan dan pernyataan dari sejumlah informan atas pencatatan keuangan yang mereka lakukan. Berikut pernyataan yang diungkapkan oleh informan I sebagai berikut:

"Tidak ada neraca keuangan, aspek keuangan yang saya perhatikan yang cuma uang masuk dan keluar saja atau biasanya hanya total kas yang saya miliki berapa gitu saja. Jadi tidak saya rinci keuangan saya secara keseluruhan, nilai dari peralatan dan perlengkapan lainnya pun 
juga tidak saya perjelas dengan nominal, hanya kalau ada peralatan rusak langsung diperbaiki atau membeli lagi yang baru gitu."

Berdasarkan hasil wawancara tersebut dapat dilihat bahwa UMKM di Kelurahan Tanjung Riau belum melakukan pembukuan yang memuat standar dari SAK-EMKM, yakni menampilkan adanya laporan posisi keuangan, laporan laba rugi, laporan perubahan ekuitas, laporan arus kas dan catatan atas laporan keuangan. Berbagai laporan yang dibuat oleh UMKM itu masih berupa laporan bisnis yang disusun atas pemahaman atau dengan cara sendiri dari pengelola/pemilik UMKM.

\section{Kendala dalam Melakukan Pembukuan Akuntansi yang Benar dan Sesuai dengan SAK- EMKM pada UMKM di Kelurahan Tanjung Riau}

Pengelolaan manajemen sebuah usaha tidak terlepas dari permasalahan yang akan menghambat tujuan dalam rangka menciptakan kemudahan pengelolaan usaha. Demikian juga dengan UMKM di Kelurahan Tanjung Riau dalam upaya menyajikan laporan keuangan yang benar dan lengkap sesuai standar yang ditetapkan dalam SAK-EMKM. Hambatan atau kendala yang dihadapi biasanya mengenai masalah waktu dan keterbatasan sumber daya manusia dalam mengelola sistem keuangan yang baik dan benar sesuai ilmu akuntansi. Penjelasan ini yang disampaikan oleh Informan I, yaitu sebagai berikut:

"Sebatas pencatatan yang saya lakukan, selama ini masih bisa saya kerjakan dengan baik, hanya saja masalah waktu kadang masih menjadi kendala, kadang saya tidak ada waktu untuk mencatat semua karena berbenturan dengan kegiatan yang lain".

"Untuk melakukan pembukuan yang benar menurut ilmu akuntansi SDMnya belum memadai karena selama ini masalah keuangan usaha saya masih saya tangani sendiri, jadi hanya sebatas pengetahuan saya. Selain itu juga tidak ada waktu untuk menyajikan pembukuan yang benar seperti dalam ilmu akuntansi."

\section{Proses Pembukuan pada UMKM di Kelurahan Tanjung Riau}

Penulis menganalisis antara kesesuaian pembukuan atau pencatatan di UMKM dengan standar pembukuan yang baku seperti yang telah diatur dalam standar akuntansi keuangan untuk usaha sejenis UMKM, yakni SAK-EMKM.

UMKM belum menyusun laporan keuangan sesuai standar dalam SAK-EMKM yang memuat komponen laporan keungan, yaitu Laporan Posisi Keuangan (Neraca), Laporan Laba Rugi, Laporan Perubahan Ekuitas, Laporan Arus Kas, dan Catatan atas Laporan Keuangan. Dengan demikian dapat disimpulkan bahwa UMKM belum menerapkan SAK-EMKM.

Laporan yang disajikan oleh manajemen UMKM dalam upaya pengawasan atau pengendalian menejemen usaha hanyalah sebatas laporan usaha yang dibuat atas dasar pemahaman pribadi yang dirasa mudah untuk mengetahui perkembangan usaha yang dijalankan.

Penyusunan laporan keuangan disajikan dengan campuran, dimana tidak ada pemisahan antara kekayaan perusahaan dengan kekayaan pribadi. Pengawasan laba rugi dilakukan secara langsung dari perhitungan uang masuk dan uang keluar dalam periode tertentu.

Dokumen-dokumen yang digunakan merupakan hasil kreasi sendiri yang disusun berdasarkan keperluan dari masing-masing UMKM. Kebijakan pengusaha UMKM dalam kaitannya dengan kesejahteraan para karyawan, maka gaji karyawan diberikan setiap akhir pekan dengan standar gaji yang ditetapkan oleh masing-masing pemilik usaha. Pemilik entitas juga memberikan bonus kepada karyawan yang rajin bekerja Kebijakan pajak dari masingmasing usah juga berbeda, bahkan ada yang tidak membayar pajak.

Entitas juga menyediakan nota penjualan sebagai bukti transaksi, namun pencatatan bukti transaksi tersebut tidak dilanjutkan sampai pencatatan dalam bentuk jurnal pembukuan akuntansi, posting ke buku besar, dan pengikhtisaran dalam neraca saldo, sampai pada pelaporan keuangan. 
Hambatan dalam menyusun laporan keuangan yang benar dan menerapkan aturan dalam SAK-EMKM mengakibatkan laporan yang disusun tidak mencerminkan proses akuntansi yang lazim diterapkan.

Hal ini menyebabkan kurang tercapainya tujuan dari penyusunan laporan keuangan, yakni untuk menyajikan informasi mengenai transaksi dan posisi keuangan, kinerja serta perubahan posisi keuangan suatu perusahaan yang bermanfaat bagi sejumlah besar pemakai dalam pengambilan keputusan ekonomi.

Laporan keuangan menunjukkan apa yang telah dilakukan manajemen atau pertanggungjawaban manajemen atas sumber daya yang dipercayakan kepadanya. Namun, tidak menyediakan semua informasi yang mungkin dibutuhkan pemakai dalam pengambilan keputusan ekonomi karena secara umum menggambarkan pengaruh keuangan dari kejadian di masa lalu dan tidak diwajibkan untuk menyediakan informasi non keuangan. Sebagai salah satu bahan pertimbangan dalam pengambilan keputusan ekonomi, laporan keuangan yang tidak benar sesuai dengan kaidah ilmu akuntansi maupun SAK yang berlaku akan menimbulkan keragu-raguan. Dalam penelitian yang penulis lakukan ini, penyusunan laporan keuangan belum menerapkan SAK-EMKM.

Laporan yang disusun masih sebatas laporan bisnis yang dibuat sendiri sesuai pemahaman masing-masing pengelola entitas. Keterbatasan pengelola entitas dalam menerapkan atau menyusun laporan keuangan sesuai SAK-EMKM disebabkan oleh beberapa faktor, sebagai berikut:

1. Keterbatasan waktu dalam mengelola keuangan usaha yang dijalankan, karena selain harus mengelola keuangan, pemilikusaha juga harus mengendalikan kinerja karyawan dan pengembangan bisnisnya dari waktu ke waktu

2. Manajemen usaha belum tahu tentang keberadaan SAK-EMKM yang mengatur standar laporan keuangan untuk jenis usaha yang mereka kelola atau bisnis yang mereka jalankan

3. Sumber daya manusia yang terbatas dari usaha yang sedang berjalan, karena pada umumnya manajemen keuangan masih ditangani dengan sendirinya oleh pemilik usaha

\section{SIMPULAN}

UMKM merupakan salah satu kegiatan usaha yang mampu memperluas kesempatan kerja, mendorong pertumbuhan ekonomi kerakyatan dan berperan dalam proses pemerataan peningkatan pendapatan masyarakat secara luas, serta dalam mewujudkan stabilitas ekonomi nasional. Potensi yang besar yang dimiliki oleh UMKM dalam menggerakkan ekonomi kerakyatan membuat UMKM memiliki posisi strategis. UMKM juga berkemampuan untuk bisa sekaligus menjadi tumpuan sumber pendapatan sebagian besar kelompok masyarakat dalam posisi peningkatan kesejahteraan.

Usaha Mikro Kecil Menengah membutuhkan strategi pengelolaan keuangan, dimana strategi tersebut dibuat dengan tujuan agar UMKM tersebut dapat berjalan dengan baik dan mampu meningkatkan produktivitas usahanya. Salah satu upaya pengelolaan keuangan adalah dengan menyusun laporan keuangan tiap periode untuk mengetahui perkembangan usaha dari waktu ke waktu. UMKM di Kelurahan Tanjung Riau Kecamatan Sekupang Kota Batam, berkaitan dengan penerapan Standard Akuntansi Keuangan untuk Entitas tanpa Akuntabilitas Publik, penulis menemukan beberapa temuan yang dijadikan kesimpualan dalam penelitian ini yaitu:

1. Manajemen hanya menyusun laporan kegiatan usaha yang mereka anggap sebagai laporan keuangan. Padahal laporan tersebut masih sangat jauh dari patuh pada standar akuntansi keuangan. Laporan tersebut digunakan untuk mengatur keuangan Manajemen Akan tetapi manajemen UMKM selalu memberikan perhatian pada ketertiban dan ketelitian dalam bertransaksi dengan penerbitan nota transaksi. Hal tersebut menunjukkan bahwa sebenarnya mereka sudah mencoba menyusun laporan yang setidaknya sudah mengarah pada kesesuaian pada standar akuntansi atau pembukuan akuntansi. 
2. Siklus akuntansi yang benar belum dilaksanakan oleh manajemen UMKM, yakni belum dimulai dengan penjurnalan transaksi, posting ke buku besar, pembuatan neraca saldo, penyesuaian, neraca lajur, sampai diterbitkannya laporan keuangan.

3. Komponen laporan keuangan yang lengkap berupa laporan posisi keuangan, laporan laba rugi, laporan perubahan ekuitas, laporan arus kas, dan catatan atas laporan keuangan belum ada ditemukan dalam laporan yang disusun oleh manajemen UMKM. Dengan demikian mereka belum menyusun laporan keuangan yang sesuai dengan SAK-EMKM.

4. Ketidakmampuan manajemen UMKM dalam menyusun laporan keuangan yang sesuai dengan SAK EMKM, disebabkan oleh beberapa hal sebagai berikut:

a. Ketidaktahuan manajemen terhadap SAK-EMKM diperlukan dalam penyusunan laporan keuangan entitas yang mereka kelola atau usaha yang mereka operasikan.

b. Pengelolaan keuangan yang masih ditangani sendiri oleh pengelola UMKM dan tidak mempekerjakan sumberdaya manusia yang sudah sesuai bidang adalah salah satu hal yang sangat krusial perlu dibenahi.

c. Adanya keterbatasan waktu dalam pengelolaan keuangan usaha, yang disebabkan oleh manajemen UMKM juga harus mengawasi kinerja karyawan dan perkembangan usaha dari waktu kewaktu, selain mengelola langsung permasalahan keuangan usaha.

\section{DAFTAR PUSTAKA}

Arikunto. (2014). Prosedur Penelitian: Suatu Pendekatan Praktik. Jakarta: Rineka Cipta.

Hetika, \& Nurul Mahmudah. (2017). Penerapan akuntansi dan kesesuaiannya dengan sak etap pada umkm kota tegal. Jurnal Akuntansi, Ekonomi Dan Manajemen Bisnis, 5(2), 259-266.

Ikatan Akuntan Indonesia. (2018). Standar Akuntansi Keuangan Ekonomi Mikro Kecil Menengah. Jakarta.

Ikatan Akuntan Indonesia. (2017). Standar Akuntansi Keuangan. Jakarta: IAI Pusat.

Indonesia, R. (2008). Undang-undang No. 20 Tentang Usaha Mikro Kecil Menengah.

Kasmir. (2014). Analisis Laporan Keuangan. Jakarta: Raja Grafindo.

Rias, T. (2009). Faktor-Faktor yang Mempengaruhi Pemahaman UMKM dalam Penyusunan Laporan Keuangan Berdasarkan SAK ETAP, 11(1), 57-64. https://doi.org/10.1161/01.HYP.25.6.1252

Sugiono. (2014). Metodologi Penelitian Bisnis. Bandung: Alfabeta. 